Volume 21 Number 1 June 2021. P. 1-26

https://doi.org/10.30603/au.v21i1.1838

\title{
Political Leadership Among Religious Minorities
}

A Study of the Books Tafsir Al-Azhar and Tafsir Al-Misbah on The Non-Muslim President

\author{
Syamsul Arifin*1, Muhammad Wahyudi ${ }^{2}$ and Muh. Mustakim ${ }^{3}$ \\ ${ }^{1}$ Universitas Muhammadiyah Malang (Corresponding Author) \\ ${ }^{2}$ Universitas Islam Negeri Sunan Kalijaga \\ ${ }^{3}$ Universitas Alma Ata
}

\begin{abstract}
This article focuses on the study of non-Muslim leadership, which is mentioned in several verses in the Qur'an and often triggers debates in the public sphere, especially at the moment of electoral politics in Indonesia. Because the discussion about this often uses verses from the Qur'an as justification, it is interesting to examine the views of the commentators in Indonesia, which is focused on Surah Al-Maidah verse 51. To explore the views of the two commentators, this study uses library research by comparing (comparative analysis) between Tafsir Al-Azhar and Tafsir Al-Misbah. The study of the opinions of the two commentators finds out that the political positions of non-Muslims as leaders for Muslims have two different views. First, not. Second, the prohibition is to make non-Muslims as auliya' then Shihab explains the position of non-Muslims in three parts, one of which is that a nonMuslim who lives in peace with Muslims has the same rights and obligations as Muslims, as well as the right to be a leader.
\end{abstract}

Keyword: Qurais Shihab, Hamka, Non-Muslim, Presiden

\begin{abstract}
Abstrak
Artilel ini fokus pada kajian tentang kepemimpinan non-Muslim yang disinggung di beberapa ayat dalam Al-Qur'an, dan sering memicu perdebatan di ruang publik terutama pada momen politik elektoral di Indonesia. Karena perdebatan tentang hal tersebut sering menyertakan ayat al-Qur'an sebagai justifikasi, maka menarik apabila dikaji pandangan para mufassir di Indonesia yang difokuskan pada surah Al-Maidah ayat 51. Untuk mengkaji pandangan kedua mufassir tersebut kajian ini menggunakan riset kepustakaan dengan cara membandingkan (analisis komparatif) antara Tafsir Al-Azhar dan Tafsir Al-Misbah. Kajian terhadap pandangan kedua mufassir tersebut ditemukan bahwa posisi politik kalangan nonmuslim sebagai pemimpin bagi kalangan Muslim terdapat dua pandangan yang berbeda. Pertama, secara mutlak tidak boleh. Kedua, larangan tersebut adalah menjadikan nonmuslim sebagai auliya' kemudian Shihab menjelaskan posisi non-muslim pada tiga bagian, satu diantaranya adalah seorang non-muslim yang hidup damai dengan muslim memiliki hak dan kewajiban sama dengan muslim, begitu juga hak menjadi pemimpin.
\end{abstract}

Kata Kunci: Qurais Shihab, Hamka, , Non-Muslim, Presiden

Author correspondence

Email: syamsarifin@umm.ac.id

Available online at http://journal.iaingorontalo.ac.id/index.php/au/index 


\section{A. Introduction}

The political problem among in Islamic circles that triggers complicated debates in the fiqh (jurisprudence) area is, among others, the right of certain religious minorities to become a top leaders in the government structure. However, it is not in a country that declares Islam as an official religion. One of the countries that may serve as the model in Indonesia. Indonesia is a country with most of the population believing in Islam; even it is the greatest country among the Muslim and Islamic countries in the world. Although it has the most significant Muslim population globally, Indonesia does not identify the concept of an official religion recognized by the state that differentiates it, for example, from Malaysia that may be included into a state with an official religion. Malaysia even is not enough to state Islam as an official religion. Still, it also mentions Islamic teaching recognized by the state as written by Pew Research Center in an article with the title of, Many Countries Favor Specific Religions, edition 3 October 2017, "In Malaysia, for example, Islam is the official religion. Many Countries Favor Specific Religions, and a 1996 fatwa required the country to follow Sunni Islam teachings in particular. Like Shiite, Ahmadiyya, and Al-Arqam Muslims, other Muslim sects are banned as deviant sects of Islam. 42 These groups are not allowed to assemble, worship or speak freely about their faith." In common sense, there is a tendency for most Muslims in Indonesia to refuse non-Muslim circles to hold the highest position in the state structure in Indonesia, namely the president. This refusal may be understood since, according to Mujar Ibnu Syarif, there is a proposition in the primary sources of Islamic laws, namely Al-Qur'an and Hadiths, that forbids the ummah of Islam to choose non-Muslim people as their leaders.

The controversy around the non-Muslim leadership came to the fore in 2017 in the momentum of the local leader election held simultaneously on 15 February 2017. The controversy was actually in Jakarta, where a regional leader election was born at that time. Still, it had a strong resonance in such a way that it affected some areas in Indonesia. In the regional leader election, three couples of candidates took part. But the couple raising the most controversy was Basuki Tjahaja Purnama, known as "Ahok," an incumbent candidate who was paired with Djarot Saiful Hidayat. In the simultaneous elections, the DKI Jakarta appeared as a 
controversial area. The controversy dealing with the nomination of Ahok is not merely on the religion Ahok believes in, but also the spread of a video and a 'transcript' of his speech of which the content is considered to insult Islam. Then Indonesian Ulema Council (MUI) issued a religious opinion and attitude regarding the Blasphemy, Insult to the Ulama, and Desecration of Al-Qur'an made by Ahok on 11 October 2016 where among others it is stated that "the statement made by the governor of DKI Jakarta is categorized into (1) insulting Al-Qur'an and or (2) the ulama with consequences". After the religious Opinion and Attitude, which are often understood as fatwa was issued, then GNPF-MUI (Gerakan Nasional Pengawal Fatwa MUI - National Movement Guarding of the MUI Fatwa) becomes the motor for Islamic Defense Action (Aksi Bela Islam) ${ }^{1}$.

According to Iqbal Ahnaf, defending Islam with the center in Jakarta has spread in various directions in Indonesia. In a Friday Sermon he followed, the material presented by the preacher dealt with the issue of non-Muslim leadership and accusations of desecrating Islam conducted by the governor of DKI, Basuki Tjahja Purnama. The preacher forbade electing a non-Muslim leader and stated the prohibition to make friends with non-Muslim people. This follows the meaning of the surah Al-Maidah verse 51 he understood as "making friends with them (nonMuslim) even becoming leaders is not allowed. ${ }^{2}$.

Such a phenomenon rampantly occurred in various mosques and also in recitations. The authority of making interpretations that no one should possess has changed. All people feel that they have the right to interpret and understand the verse following their understanding. It is no wonder that various spreading interpretations are "intolerant" in nature, accompanied by sentiment to other groups. Therefore, this article would discuss the opinions of the two Indonesian mufassirs, namely Hamka and M. Quraish Shihab, about the surah Al-Maidah verse 51. Is there any difference in points of view between the two figures, and what backgrounds the differences?

\footnotetext{
1 Ahmad Najib Burhani, "Aksi Bela Islam: Konservatisme Dan Fragmentasi Otoritas Keagamaan," Jurnal Maarif Institute, 2016, p. 36.

2 Mohammad Iqbal Ahnaf, '“Aksi Bela Islam,' Akankah Mengubah Lanskap Muslim Indonesia?," Maarif, 2016, p.30-31.
} 


\section{A. The Biographical Sketch of the Two Mufassirs}

Hamka (Haji Abdul Malik Karim Amrullah) is a descendant of Tanjung tribe from Abdul Arief family, a Paderi hero with the title of Tuanku Pauh Pariaman atau Tuanku Nan Tuo ${ }^{3}$. Hamka was born in Sungai Batang, Maninjau, on Pebruary 17, 1908 at the same time with 14 Muharram, 1326 Hijriyah. His father is a wellknown Ulema in Minagkabau, namely Haji Abdul Karim Amrullah. His mother's name is Siti Safiyah, the daughter from Gelanggang with the title of Baginda Nan Batuah4.

Professor Dr. Buya Haji Abdul Malik bin Abdul Karim Amrullah is known among Indonesian Muslims as Buya Hamka, taken from his name. He is identified as a self-taught person. ${ }^{5}$. Since Hamka was a child, he liked to read either religious books or local tales. Once, his father decided whether he wanted to become a religious person or a storyteller. ${ }^{6}$. Almost all of the education Hamka obtained was from his father as a religious expert in his local area. In the formal education, he went to school up to the third grade in the village school, and he also studied in a religious school in Padang Panjang and Parabek for three years. However, with the scientific spirit, he traveled to various areas to gain science informally.7.

At the age of 16, he had left Minangkabau for Yogyakarta. He knew and gained knowledge of a movement from Islamic activists in this city, such as HOS Tjokroaminoto (Sarekat Islam), Ki Bagus Hadikusumo (Muhammadiyah), and some other prominent figures. Hamka also became a member of Sarekat Islam at that time. Up to the mid-1925, Hamka returned to Padang Panjang and established Muhammadiyah in his father's home. ${ }^{8}$. Two years after returning from Java, Hamka went to Mecca to make a pilgrimage. On this occasion, he broadens his knowledge and experiences. In Mecca, Hamka worked in a printing company for six months. After that, he returned to Indonesia and started being active in the world he worked on either as a religious figure, an activist, a politician, or a writer.

\footnotetext{
${ }^{3}$ Hamka, Ayahku: Riwayat Hidup Dr. H. Abdul Karim Amrullah Dan Perjuangan Kaum Agama Di Sumatera, 1982, p.36.

${ }^{4}$ Nasir Tamara, dkk, Hamka Di Mata Hati Umat (Jakarta: Pustaka Sinar harapan, 1996, p. 51.

${ }^{5}$ M. Bibit Suprapto, Ensiklopedia Ulama Nusantara (Jakarta: Gelagar Media indonesia, n.d.), p. 334.

${ }^{6}$ Nasir Tamara et. al, Hamka Di Mata Hati Umat, p. 368.

${ }^{7}$ M. Bibit Suprapto, Ensiklopedia Ulama Nusantara, p. 334.

8 A. Susanto, Pemikiran Pendidikan Islam (Jakarta: Amzah, 2009), p. 98.
} 
In 1928, Hamka attended a Muhammadiyah Conference in Solo. Returning from the Conference, Hamka began to hold some crucial positions in Muhammadiyah, and at last, he was appointed as the Chairman of Muhammadiyah in the 32nd Muhammadiyah Conference in Purwokerto in 19539. In the previous year, when Hamka was a high official and the adviser of the Department of Religion, the government of the United States of America once invited him to stay in the country for four months. During his stay in the US, Hamka had a more open view of non-Islamic countries. Returning from the United States of America, he published his travel book "Empat Bulan di Amerika Serikat" (Four Months in the United States) for two volumes. After that in succession, Hamka became a member of the cultural mission to Muangthai (1953), represented the Department of Religion to attend the commemoration of the death of Budha in Birma (1954), participated at an Islamic Conference in Lahore (1958), and an invitation from the Al-Azhar University to give a speech on the effects of Muhammad Abduh in Indonesia. The speech caused him to be given an Honorary Doctorate Degree. ${ }^{10}$.

Besides being active in Muhammadiyah and the Department of Religion, Hamka was also known to be involved in the political world. He was one of the members of the Masyumi Party after the Independence of Indonesia. Up to 1955, in the general election, Hamka was elected as a member of the Constituent Assembly representing Central Java. ${ }^{11}$. In the Constituent Assembly, Hamka, together with Mohammad Natsir, were the loudest and the most consistent party to struggle the Islamic laws to become the basis of the Indonesian state. However, the hard work proposed by his colleagues failed after Soekarno dissolved the Constituent Assembly on 5 July 1959.

After the decree of the dissolution, it can be stated that the journey made by Hamka in the political world had ended since President Soekarno dissolved the party he kept. His uncompromising attitude towards religion was often classed with some government policies, and this caused him to be sent to jail from 1964 to

\footnotetext{
${ }^{9}$ Shobahussurur, Mengenang 100 Tahun Haji Abdul Malik Karim Amrullah (Hamka) (Jakarta: Yayasan Pesantren Islam al-Azhar, 2008), p.24.

10 Yunan Yusuf, Corak Pemikiran Kalam Tafsir Al-Azhar (Jakarta: Pustaka Panjimas, 1990), p. 48-49.

${ }^{11}$ Herry Mohammad, et. al, Tokoh-Tokoh Islam Yang Berpengaruh Abad 20, (Jakarta: Gema Insani, 2006), p. 57.
} 
1966. In the custody ${ }^{12}$, Hamka finished writing a book with the title of Tafsir AlAzhar for 30 volumes ${ }^{13}$. After being released from prison in 1977, he was elected as the first chairman of the Indonesian Ulama Council (MUI). The position was held up to mid-1981. He resigned from the position ${ }^{14}$ since the fatwa issued by the MUI regarding the prohibition of commemorating Christmas Day for Muslims was not given proper attention by the government. Even Mr. Alamsyah Ratu Prawiranegara, the Minister of Religion at that time, lashed out at the fatwa and asked that it should be repealed.15.

On 24 July 1981, two months after resigning from his position as the chairman of MUI, he passed away at 73 years old. ${ }^{16}$. He left various works he wrote among his activities from either a religious figure, a civil servant to a politician, namely among others: Di Bawah Lindungan Ka'bah, Tasawuf Modern, Negara Islam, Tenggelamnya Kapal Van Der Wijk, Islam dan Demokrasi, Tafsir Al-Azhar and other's ${ }^{17}$.

Meanwhile, M. Quraish Shihab was born in Rappang, South Sulawesi, on 16 February 194418. He is of educated Arab descent. His father's name is Abdurrahman Shihab (1905-1986), and he is an alumnus of Jam'iyyah al-Khair Jakarta, the oldest Islamic Institution putting forward modern Islamic ideas. Besides a professor on interpretation, his father once also held a position as the Rector of IAIN Alaudin Ujung Pandang and was noted as the founding father of Universitas Muslim Indonesia (UMI) Ujung Pandang.

As the son of a prominent figure in the world of education, especially in interpretation, M Quraish Shihab got a primary motivation and the seed of loving the Al-Qur'an from his father. ${ }^{19}$. Since he was seven years old, he permanently joined in studying Al-Qur'an held by his father. Moreover, his father often invited

\footnotetext{
12 Herry, p.57.

13 Achmad Syahrul, Penafsiran Hamka Tentang Syura in Tafsir Al-Azhar (Fakultas Ushuluddin dan Pemikiran Islam, 2009), p. 22.

14 Herry, Tokoh-Tokoh Islam Yang Berpengaruh Abad 20, p. 60.

15 Yunan Yusuf, Corak Pemikiran Kalam Tafsir Al-Azhar, p. 52-53.

16 Yunan Yusuf, p. 52-53.

17 Nasir Tamara, et. al, Hamka Di Mata Hati Umat, p. 142.

18 M. Quraish Shihab, Membumikan Al-Qur'an: Fungsi Dan Peran Wahyu Dalam Kehidupan Masyarakat (Bandung: Mizan, 2007), p. 7.

${ }_{19}$ Muhammad Dian Supyan, "Kepemimpinan Islam Dalam Tafsir Al-Misbah Karya M Quraish Shihab" (UIN Sunan Kalijaga, 2013).
} 
his children to sit together and asked them to read Al-Qur'an, and then he explained stories in Al-Qur'an. It is this time that his father presented various religious advice. He then realized that the advice offered by M. Quraish Sihab's father turns out to be the verses of Al-Qur'an, the Prophet's words, advice from the comrades or experts in the interpretation of Al-Qur'an touching his heart. ${ }^{20}$.

His formal education started from elementary school in Ujung Pandang, then Junior High School in Malang while he served as a santri in Pondok Pesantren Darul Hadis al-Falaqiyyah. To deepen his Islamic study, Shihab was sent by his father to al-Azhar, Cairo, in 1958, and he was accepted in the second grade of Tsanawaiyah (equivalent to Junior High School). Then, he continued his study at the Al-Azhar University, Cairo, Egypt, in the Ushuluddin Faculty, the Interpretation and Hadiths Department. He obtained the title of L.C. In 1967. Two years later, in 1969, M. Quraish Shihab succeeded in getting his M.A. title in the same department with the title of his thesis of al-I'jaz al-Tashri' li al-Qur'an al-Karim ${ }^{21 .}$

In 1973, his father asked him to return to Ujung Pandang to help manage the education in IAIN Alaudin. At that time, his father held a position as the rector. M. Quraish Shihab was appointed as the vice-rector in the academic and students' affairs until 1980. Besides holding the position, he often substituted his old-aged father to manage specific tasks. Successively, Quraish Shihab was handed over various positions, such as the Coordinator of Private Universities in Area VII for East Indonesia in mental education and a series of other positions out of campus. Among his activities, he could finish some researches among others Penerapan Kerukunan Hidup Beragama di Indonesia (1975) and Masalah Wakaf Sulawesi Selatan $(1978)^{22}$.

Then in 1980, Shihab returned to Egypt to continue studying in the same field and alma mater, Al-Azhar University, Cairo. Two years later, he finished his dissertation with the title Nazm ad-Durar li al-Biqa'i Tahqiq wa Dirasah. Therefore, 14.

${ }^{20}$ Shihab, Membumikan Al-Qur'an: Fungsi Dan Peran Wahyu Dalam Kehidupan Masyarakat, p.

21 A'an Suryana, "Islam Dan Urusan Kemanusiaan: Konflik Perdamaian Dan Filantropi," Global South Review, 2017, p. 169. https://doi.org/10.22146/globalsouth.28855.

${ }^{2}$ Hasan Muarif Ambary, "Suplemen Ensiklopedi Islam," in Ensiklopedi Islam, (Jakarta: Ikhtar Baru Von Hoeve, 2004), p. 111. 
he obtained a doctoral degree in Al-Quran Science with the judicium of Summa Cum Laude with Appreciation Level I (Mumtaz ma'a martabat al-sharaf al-ula). He became the first person in Southeast Asia who got a Doctoral Degree in Al-Quran Science in the Al-Azhar University, Cairo, Egypt. Returning to Indonesia, Shihab did not teach in IAIN Alaudin, but he was transferred to the Faculty of Ushuluddin, IAIN Syarif Hidayatullah (now UIN) Jakarta. Then, because of his expertise in the field of al-Qur'an study, he was trusted to become the Rector of IAIN Syarif Hidayatullah Jakarta (now UIN) for two periods (1992-1996 and 1997-1998). Besides working in the academic field, he also took part in the Central Indonesian Ulema Council as the chairman from 1985-1998, a member of the People's Consultative Assembly of the Republic of Indonesia 1982-1987 and 1987-2002. In 1998, he was trusted to become the Minister of Religion of the Republic of Indonesia. His main activity right now is that he often appears in various media to give spiritual and intellectual advice and serves as a professor in the Post-graduate Program of UIN Syarif Hidayatullah Jakarta and the Director of the Center for AlQur'an Study (PSQ) Jakarta. ${ }^{23}$.

Among his activities, Shihab is also involved in various scientific activities in or out of the country. What is also important is that He is also active in writing activities in the rubrics "Pelita Hati," he also manages the title "Tafsir Al-Amanah" in the biweekly magazine published in Jakarta. Some books he has written among others are Membumikan Al-Qur'an, Wawasan Al-Qur'an; Tafsir Maudhu'i atas Pelbagai Persoalan Umat. The second book is the bestseller book since it was sold more than 75.000 ex in its first edition. And in the second edition up to the year 2000, it had been printed 11 times. Moreover, there are still many other works by M. Quraish Shihab that have become references by the Muslim society in Indonesia, such as Tafsir Al-Misbah. ${ }^{24}$.

${ }^{23}$ M. Quraish Shihab, Lentera Al-Qur'an: Kisah Dan Hikmah Kehidupan (Bandung: PT Mizan Pustaka, 2014), p. 5.

${ }^{24}$ A Complete Interpretation of Al-Qur'an for 30 Juz was written by M. Quraish Shihab and was first printed in 2000. This interpretation was written with the mushaf arrangement (tartib mushafi) with more than 10.000 pages consisting of 15 significant volumes. 


\section{B. The Books Tafsir Al-Azhar dan Tafsir Al-Misbah}

\section{Tafsīr Al-Azhār}

At first, the book Tafsir Al-Azhar is a material for the study of interpretation in the Subuh lecturing managed by Hamka in the Masjid Agung Kebayoran Baru (the name was replaced into the mosque Al-Azhar after it was officially opened by Grand Syaik Al-Azhar University, Syaik Mahmoud Syaltour in 1960). The study began from the surah al-Kahfi (juz 150 in series since 1962, then it was published in the magazine Gema Islami since 1962, and it lasted for two years. But, according to another source, the Subuh lecturing had been held since 1958 and 1959. Meanwhile, for the searches in the existing literature made by the author, the Subuh lecturing began in 1962, and two years later, it was stopped since Hamka was sent to jail (1964-1966).

Hamka's desire to finish the book Tafsir Al-Azhar was more potent when he was in prison. Even the writing of the Tafsir Al-Azhar completely finished for 30 juz some days before he was moved to the house arrest. During the house arrest, Hamka completed some parts of the books that he felt incomplete yet. The book Tafsir Al-Azhar was then published by three publishers: Juz 1-4 by Pembimbing Masa Publisher, juz 15-30 by Pustaka Islam Surabaya, and juz 5-15 by Yayasan Nurul Islam Jakarta. It was also entirely published by Pustaka Nasional Singapura in 10 volumes. It was also wholly published in Malaysia. Meanwhile, in Indonesia, it was wholly published by Panji Mas in 15 volumes and Gema Insani Publisher in 9 volumes. ${ }^{25}$.

The writing of the book Tafsir Al-Azhar is based on Hamka's concern with some previous interpretations that tended to ta'asub (defend) it is own religious teaching. He also intended to answer the ummah's needs for a study revealing the

25 Shobahussurur, Mengenang 100 Tahun Haji Abdul Malik Karim Amrullah (Hamka); Akhsanul In'am Muh. Mustakim, Syamsul Arifin, Moh Nurhakim, Spiritualisasi Pendidikan Qur'ani (Cilacap: Pasific Press, 2020). 
secrets of Al-Qur'an, to leave a legacy for the ummah of Islam, and to thank for the Honorary Doctorate from Al-Azhar University. ${ }^{26}$.

The writing of the book Tafsir Al-Azhar tends to the interpretation of bi alma'sur, as known as Ibnu Taimiyah. But, Hamka tried to elaborate his writing into the modern Islamic History, the study of Al-Qur'an, and contextualize it into the condition of the era. Hamka himself acknowledged that the writing of the book Tafsir Al-Azhar was inspired from the style of Muhammad Abduh and Rasyid Ridha when they wrote the Tafsir Al-Manar, namely they describe meanings of the interpretation of a verse of Al-Qur'an and explain the related hadiths, fight, history, and other 'ulum ad-diniyahs, all of which are then contextualized into the sociopolitical condition when the Tafsir Al-Azhar was written. Therefore, the style and the tendency of the book Tafsir Al-Azhar is under the category of the interpretation of al-adab al-ijtimā' $i$ in the Al-Farmawi'd perspective. Hamka also often interpreted a verse and other verses as Ibnu Kasir and others did. According to this perspective, this interpretation should be categorized into the interpretation of AlQur'an bi Al-Qur'an.

However, Nasrudin Baidan viewed that the book Tafsir Al-Azhar is a combination of the interpretation of bi al-ra'y and bi al-ma'sūr. Viewed from its presentation, the book Tafsīr Al-Azhār is made by using the tahlil method, namely interpreting verse per verse after being grouped into a subsection. As a writer, Hamka's language style in the interpretation is interesting enough, especially in the word's arrangement. ${ }^{27}$.

Hamka composed the book Tafsir Al-Qur'an in a different way from those of his predecessors. Besides writing in Indonesian (instead of Arabic), the writing system is constructed through six stages. Firstly, some verses (1-5 verses) at the beginning of the discussion are grouped. Secondly, the translation in Indonesian (or Malay for the publication in Malaysia and Singapore) is presented. Thirdly, munasabah among verses is made. Fourthly, Verses are globally described. Fifthly, asbāb an-nuzūl is described. Fifthly, the interpretation of a verse that is correlated

${ }^{26}$ Malkan Malkan, "Tafsir Al-Azhar: Suatu Tinjauan Biografis Dan Metodologis," HUNAFA: Jurnal Studia Islamika, 2009, Https://Doi.Org/10.24239/Jsi.V6i3.146.359-376.

27 Nashruddin Baidan, “Wawasan Baru Ilmu Tafsir,” Buku, 2016. 
with the era's reality is described in detail. What differs between this interpretation and others is that Hamka does not detail linguistical explanations or the word structures from the verses studied. ${ }^{28}$.

The book Tafsir Al-Azhar is incredibly welcome by the people in Indonesia, even in Southeast Asia. In the introduction for the publication in Singapore, Shed Ahmad Semait greatly praises the Tafsir Al-Azhar. The praise is initiated by comparing it with the those made by Sayyid Qutb and Sa'id Hawwa, where this interpretation was intensively written even during the exile in prison. Even Syed Ahmad explicitly stated that Tafsir Al-Azahr is excellent to work, so that it is they with good luck and guidance who have a chance to read it. ${ }^{29}$.

The Book Tafsīr Al-Miṣbāh

Tafsir Al-Miṣbāh is composed by Quraish Shihab, 30 juz in 15 volumes when he served as the ambassador in Cairo. The writing process is different from that namely when Al-Azhār, Al-Asās Fi Al-Tafsīr, or Fi Zilāl Al-Qur'an, was written where the author was in jail. The power of Quraish Shibah, amid his activities as the ambassador, makes the Tafsir Al-Misbah rich of sources of literature references. Although when it is further traced, this interpretation began and finished when Indonesia was in the transition period from the new order to the reformation order and during the monetary crises period (8 June 1999 to 5 September 2003). Moreover, Quraish Shihab held a position as the last Minister of Religion under the administration of President Soeharto. It means that although Quraish Shihab was not in custody, the socio-political and cultural situation at that time was not promising and uncertain. ${ }^{30}$

Many writers explained that the name "Al-miṣbāh" is from Arabic المصباح, that means lamp, lantern, or light. Therefore, it is expected that this interpretation becomes a light for the ummah in understanding Al-Qur'an as hudan li an-nās

28 Baidan; Malkan, "Tafsir Al-Azhar: Suatu Tinjauan Biografis Dan Metodologis."

${ }^{29}$ Norbani B. Ismail, "The Qur'anic Exegesis, Reformism, and Women in Twentieth Century Indonesia," Studia Islamika, 2017, https://doi.org/10.15408/sdi.v24i3.5187; Malkan, "Tafsir AlAzhar: Suatu Tinjauan Biografis Dan Metodologis."

30 Dedi Junaedi, "Konsep Dan Penerapan Takwil Muhammad Quraish Shihab Dalam Tafsir AlMishbah," Wawasan: Jurnal Ilmiah Agama Dan Sosial Budaya, 2017, https://doi.org/10.15575/jw.v2i2.1645; Atik Wartini, “Corak Penafsiran M. Quraish Shihab Dalam Tafsir Al-Misbah," Hunafa: Jurnal Studia Islamika, 2014, https://doi.org/10.24239/jsi.v11i1.343.109-126. 
(guidance for humankind) is a necessity. Five matters background the reasons for writing this interpretation. The first is to give away of easiness in understanding Al-Qur'an and to be able to catch the messages and impressions so that they may be reflected in daily life. To the author's best knowledge, the reason is in line with efforts made by Quraish Shihab, who wrote and explained how to ground AlQur'an systematically. The second is to criticize the Indonesian Muslims who tend to make mistakes in interacting with Al-Quran; a tradition to read surah Yasin often without understanding the meanings and the messages it contains. The indicator is evident due to the more substantial and higher number of the fadilah of certain verses written in Indonesian. The third is the criticism of the mistakes made by academicians in discussing Al-Qur'an, which should become the "spirit" of the Al-Qur'an education itself. The fourth is the motivation from Indonesian Muslim circles to write interpretation in Indonesian. The fifth is an effort to perfect previous interpretations. ${ }^{31}$.

The book Tafsir Al-Miṣbāh was written by referring to the order of mushaf uśmānī; from sūrah al-fatihah to sūrah an-Nas. Verse per verse and surah per surah interpreted with each analysis show that this interpretation uses a correct analytical method. The interpretation style used tends to adabi-ijtima'ii, namely connecting meanings and interpretations of verses of Al-Quran. They are contextualized in daily life, including solving various problems the ummah faces in line with the detailed expressions from the order, language, and the goal of AlQuran. Quraish Shihab also emphasizes the effort to prove the ideals of Al-Qur'an șāliḥ li at-tațbīq fi kulli zamān w-a-l makān either substantively or applicatively.

Under the hermeneutic perspective of Al-Qur'an, the book Tafsīr Al-Miṣbāh tends to be a quasi-objective modernist than objective or subjective traditionalist. Because the interpreter uses meanings of the verses of Al-Quran in line with their asbāb an-nuzūl, nāsikh-mansukh, muhkkam, and its mutasyābih, and then it is used

31 Lufaefi Lufaefi, "Tafsir Al-Mishbah: Tekstualitas, Rasionalitas Dan Lokalitas Tafsir Nusantara," Substantia: Jurnal Ilmu-Ilmu Ushuluddin, 2019, https://doi.org/10.22373/substantia.v21i1.4474; Junaedi, “Konsep Dan Penerapan Takwil Muhammad Quraish Shihab Dalam Tafsir Al-Mishbah." 
as a nuqtah at-talaqqi for the readers. It needs to produce contextual interpretations. ${ }^{32}$.

Quraish Shihab is not the only expert on the interpretation of Al-Qur'an in Indonesia. Still, his real expertise in interpreting Al-Qur'an in the present contexts and his high productivity make him become a well-known interpreter of Al-Qur'an in Indonesia. One of the superiorities of the book Tafsir Al-Misbah is the occurrence of dialogues of the classical and contemporary interpretation models. Quraish Shihab has emphasized the expression of meanings, harmony, and contextualization of verses without ignoring the development of science. Although it tends to the interpretation of bi ar-ra'yi or bi ad-dirāyah because of massive istinbāt and ijtihad in expressing meanings, Quraish Shihab often refers to previous interpreters such as Ibnu Kas̄īr, Ar-Rāzī, al-Baqā'i, Tanțāwi, Asy-Sya'rawi, Sayyid Quțb, Ibnu 'Asyur to Tabațaba'i. If he does not refer to them, Quraish Shihab will provide the interpretation with hadiths or various stories explaining the meaning of a verse. ${ }^{33}$.

In the author's opinion, the Tafsir Al-Misbah tends to combine the interpretation of bi ar-ra'yi and bi al-ma'sūr. However, what is more, dominant is the interpretation of bi ar-ra'yi. This domination is a consequence of the effort to contextualize Al-Qur'an. Since Quraish Shihab indeed interprets each verse to explain its message through either linguistic explanation or the origin of a verse or a surah, then he reconstructs the harmony lafaz by lafaz in a surrah, the harmony between munasabah of the verse and the surah, and a verse and the next one. He also sees the harmony among surahs, namely the end and the beginning of a surah, and the harmony between the theme of a surrah and the naming of the surah itself.

The systematic construction in Tafsir Al-Misbach is begun by mentioning the name of a surah, the number of verses, and the place where the verse came down. Even the numbering of the surah from the makkiyah or madaniyah perspective sometimes is also mentioned. The next step is to note the central theme, the goal of

32 M. Quraish Shihab, Tafsir Al-Misbah: Pesan, Kesan Dan Keserasian Al-Qur'an (Ciputat: Penerbit Lentera Hati, 2011); Baidan, "Wawasan Baru Ilmu Tafsir"; Lufaefi, "Tafsir Al-Mishbah: Tekstualitas, Rasionalitas Dan Lokalitas Tafsir Nusantara."

33 Shihab, Tafsir Al-Misbah: Pesan, Kesan Dan Keserasian Al-Qur'an; Lufaefi, "Tafsir AlMishbah: Tekstualitas, Rasionalitas Dan Lokalitas Tafsir Nusantara." 
a surah or a verse, and it is accompanied by the ulemas' opinions in explaining the theme studied. To complement the discussion of the theme, Quraish Shihab describes the munāsabah between verses (before and after the verse) and explains the asbāb an-nuzūl sūrrah or verse (if it exists). In general, the writing of the book Tafsīr Al-Miṣbāḥ is in line with that of al-wiḥdah al-mauḍu'iyah owned by Sayyid Quṭb and waḥdah Al-Qur'aniyah belonging to Sa'īd Hawwa, called with the term of the harmony of Al-Qur'an. ${ }^{34}$.

\section{The Interpretation of Surah Al-Maidah Verse 51 in the Two Tafsir Books}

In the book Tafsir Al-Azhar, Hamka interprets Surah Al-Maidah verse 51 as follows:

"O, believers! Take neither Jews nor Christians as guardians-they are guardians of each other. Whoever does so will be counted as one of them. Surely Allah does not guide the wrongdoing people."

Then he explains that for the believers, due to the consequences from their faith, they do not submit their leadership to Jews, Christians, or the people that should not know the believers' secrets since this will not solve problems except raising other issues.

Moreover, Hamka explains in the verse that mentioning groups using Jews and Christians, instead of Ahlul Kitab is caused, according to the experts in AlQur'an interpretation, by the fact that in the central teachings of their books, there is no teaching that opposes to monotheistic teachings brought by the Prophet Muhammad SAW, regardless of the ta'ashub or fanaticism, the previous books do not contradict with Al-Qur'an. But, then, after fanaticism exists, any teachings which are in line with Islam are left out. ${ }^{35}$.

When they make Jews and Christian leaders, although the leaders are just some of them, they will stay close to those with the same views. They will not carry out their duties as leaders wholeheartedly because they still follow their origins; namely, they are hostile to Islam. Dealing with belief, Jews and Christians are considerably different. Jews presume that Maryam has committed adultery and Isa is not God's son. Jews are hostile to Christians and vice versa. However, when they

\footnotetext{
${ }^{34}$ Junaedi, "Konsep Dan Penerapan Takwil Muhammad Quraish Shihab Dalam Tafsir AlMishbah"; Wartini, "Corak Penafsiran M. Quraish Shihab Dalam Tafsir Al-Misbah"; Shihab, Tafsir AlMisbah: Pesan, Kesan Dan Keserasian Al-Qur'an.

35 Hamka, Tafsir Al-Azhar, 3rd ed. (Singapura: Kerjaya Print, 2007), p. 1761.
} 
would face Islam, although they hate one another, They will help one another. ${ }^{36}$. Then, Hamka reinforced his explanation by proposing a historical argument:

It once happened in Bandung when the Republic of Indonesia had elected the Constituent Assembly members. The representations of Islamic parties urged that in the Constituent that would be established, seven sentences were included: "With an obligation to carry out the Islamic Laws for its adherents." Then all parties hating the Islamic ideals supported, led, gave, and opposed the ideals of one another, although they had different ideologies and interests. In facing Islam, they united. Catholic, Protestant, National parties, Socialist parties, and Communist parties united."

This was also the case in the international arena." In 1964, Pope Paul VI, as the highest chairman of the Catholic churches, gave a general pardon for Judaism. They are freed from any sins they have been accused of so far, namely because it is their efforts that the Prophet Isa Almasih was arrested by the Roman rulers and was submitted to Jews, and then he was crucified (according to their belief).

Now, after Twenty centuries, Jews have been cursed and insulted everywhere in the Christian world, immediately the Pope gave them a pardon.

What kind of pardon is it? The belief that has been lasting for 2000 years may be immediately changed!

It is a "political pardon" The Jews with significant economic resources should unite with Christians to face the danger of Islam. Then in 1967, Arabian countries were attacked by Jews for four days, and Jerusalem (Baitul Maqdis) was seized from the hand of Muslims. The hereditary authority for more than 1,300 years from the Arabians should be given to one International body. Explicitly it should be submitted to the United Nations, where the Christian countries fully control it. (France, Catholic; America, Protestant; England, Anglican, and Rusia, Communist) ${ }^{37}$.

During the Prophet Muhammad era, in Madinah, such cooperation did not exist since Judaism was the most significant religion in Madinah at that time, besides Islam. Meanwhile, Christianity developed well in Syria (north) and Yemen Najran (south). Then Hamka states that the miracle of al Qur'an may be felt with historical travel. Two religions that were at first hostile to one another, namely Judaism and Christianity, then help one another. At last, Israel, the country could be established among Islamic countries with the help of Christians. They do not take an issue with their conflicting beliefs. but they choose to help and support one

\footnotetext{
${ }^{36}$ Hamka, p. 1761-1762.

${ }^{37}$ Hamka, p. 1762.
} 
another to fight against Islam opposing Jewish belief that Isa is the child of adultery and the Christian belief that Isa is God's son ${ }^{38}$.

The next syllables are "whoever does so will be counted as one of them" the fragment of this verse means that it impossible for one who makes another his leader to do not like him and does not have any empathy to him. But, one's preference for another with different religion does not make him out of his religion officially. then, Hamka cites words of Huzaifa bin al-Yaman, one of the Prophet's comrades who once became a war officer: "be careful about each one of you, that he has become a Jew or a Christian, but he does not feel so ${ }^{39}$." then this verse is read, namely if people have become their leaders, they have entered into the groups of people they had appointed as the leaders ${ }^{40}$.

In the history of Christian colonialism over countries with Muslim populations, the colonialists' first thing is to teach their language to the Muslim population. The expectation that the colonized Muslim people think using the colonialist's language. Then they started being weak in their language and being affected by the colonialist's civilization and cultures (Christians). When time passed, their identity and also their way of thinking and language development would fade. Therefore, they would think that the colonialists possessed higher dignity than they did. This was once experienced by Indonesia when it was colonized by the dutch, north Africa by french, the Malay world (Malaysia), and India by the British. As a result, it is more difficult to explain religious teachings to the indigenous people whose thoughts had been contaminated than the Americans or Europeans who want to believe in Islam.

Then, Hamka criticized the indigenous people who name themselves as "intellectual men," asking for information that makes sense about a religion. This certainly is caused by the education given by the colonialist that has planted some doubts in anything, including the religion they believe in. It can be that they are brilliant and rational, but their soul might change. Good things are from the colonialist country, while anything born from their religion and country is

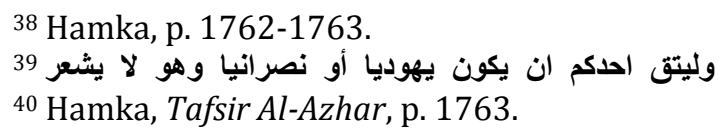


considered to be wrong. Hamka cited a statement made by Ibnu Khaldun in his Muqqaddimah that the losers tend to imitate those who beat them, either in the symbol, how to dress, habits, and their customs. Because the losers believe that perfection only exists in those who have beaten them. As a result, they merely carry out their religious laws and forget the essence of their religion. ${ }^{41}$.

Moreover, Hamka explained that making the colonialists (Christians) leaders will imply that the colonized people will not mind selling their religion and country. Hamka said that when the dutch was overwhelmed in facing the people of Aceh, they brought a Muslim prosecutor from out of Aceh. The colonialist noted that the prosecutor should be able to beat the people of Aceh at that time, and at last, Aceh could be defeated by the dutch. Supposedly, the prosecutor is a person with an excellent devotion to religion. He got a willemsorde star from the dutch for his services in beating the people of Aceh, whose religion is the same as his.

The last syllables read, "surely Allah does not guide the wrongdoing people. "it can be understood that making jews and Christians as leaders are wrongdoing (zalim) and persecution act. The word zalim (ظالم) (ظلم) is from the word zulm), meaning dark. Therefore, they are grouped into the people who choose a dark way, where Allah does not give a bright light.

Hamka thought that the surah al-Maidah verse 51 forbids the people of faith to make jews and Christians their leaders. But if one merely makes them his partners in economic or social affairs, this doesn't matter. In the surah al-Hujurat verse 13 , it is stated that:

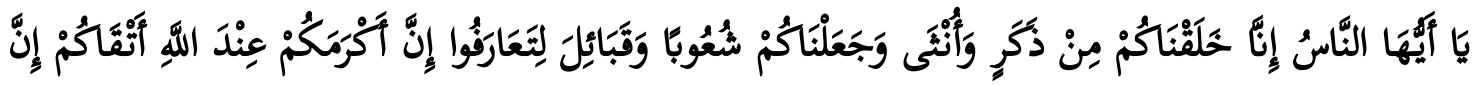

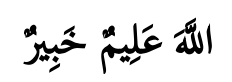

:Translation

O humanity!. Indeed, We created you from a male and a female and made you into peoples and tribes so that you may 'get to' know one another. Indeed, the noblest of you in the sight of Allah is the most righteous among you. Allah is truly All-Knowing, All-Aware.

${ }^{41}$ Hamka, Tafsir Al-Azhar, p. 1764; Latifatul Izzah, "Melihat Potret Harmonisasi Hubungan Antar Umat Beragama," Jurnal Studi Agama-Agama Kompetensi Damai Dalam Keragaman 9, no. 1 (2013), p. 1-22. 
In the economic affairs, the Prophet once pawned his shield to his neighbor, a jew. Moreover, the Prophet also slaughtered a goat and asked one of his colleagues to deliver it to his neighbor, a jew. Then in Islamic law, a Muslim man may marry a woman from the scribe because, in a household ark, a husband is the family leader. However, a Muslim woman cannot marry a man from the writer, except the man, believes in Islam first. ${ }^{42}$.

In government affairs, the rulers of Islam are allowed to trust the adherents of other religions to hold important positions in the government. This is based on the fact that the highest position is under the hand of Islam. As a result, it is not necessary to be afraid of any rebellion or breach of trust. But, if it is worried that unintended cases would occur, such an assignment is not allowed. ${ }^{43}$.

After interpreting the surah al-Maidah verse 51 at length, Hamka explained the sabab nuzul of this verse. He stated that there are some different stories about the coming down of this verse, one of which is the betrayal conducted by Jews from Bani Nadhir. It is also mentioned that the residents of Madinah Arab, namely the Khazraj and Aus tribes, before embracing Islam, had agreed with the Jewish tribe in Madinah, namely Bani Nadhir, Quraish, and Qainuqa, to help one another. After the kharaj and Aus tribes believed in Islam and the Prophet Muhammad moved to Madinah, an agreement to live peacefully between Islam and Judaism was made. If Madinah was attacked, they should also help one another. Moreover, the Prophet Muhammad also provided a guarantee of freedom to them in believing in religion.

But not long after the agreement was made, one of the Jewish tribes, namely Bani Nadhir, betrayed the agreement by planning to kill the Prophet Muhammad when the Prophet visited their village. But the effort failed. Being supported by some evidence, the tribe was surrounded by Muslim people, and then it was expelled from the place. Moreover, the betrayal was also carried out by other tribes, namely the Jew from Bani Quraizah in the al-Ahzab (khandaq war) by leaking the enemy power to the polytheists in Mecca. Since they had broken the agreement that had been agreed upon, the Jews from Bani Quraidzah were punished, all men were killed, and their children and wives were taken into

42 Hamka. p. 1765.
43 Shihab. p.1766.

https://doi.org/10.30603/au.v21i1.1838 
prisons, and their property was deprived. Some of the betrayals become one of the stories in the sabab nuzul of this verse. ${ }^{44}$.

Although there are some stories of sabab nuzul about this verse, Hamka argued that what is used as the guideline is the content of the verse. This opinion is reinforced by one of the rules of the ushul fiqh:

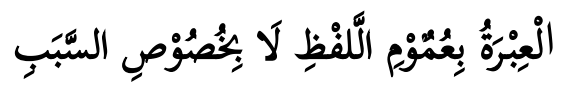

What is meant is the general meaning of the words, not specifically the cause

It means that what is made as the basis is the intention and the goal of words (lafadz) instead of the cause of the coming of the verse. Therefore, this prohibition valid forever to keep the Islamic teachings. ${ }^{45}$.

Meanwhile, in the book Tafsir Al-Misbah, one of the characteristics of interpretation made by M. Quraish Shihab is describing the meaning of word per word in a detailed manner so that a comprehensive understanding of the words in the interpreted verse may be reached. Different from Hamka in interpreting the surah Al-Maidah verse 51, M Quraish Shihab does not interpret the word auliya' into leaders as given by Hamka in his book Tafsir Al-Azhar. Shihab prefers to write the word auliya' in the translation. Because for him, the word auliya' does not mean leader.

M. Quraish Shihab disagrees with translating the word auliya' into leaders as conducted by the Team of the Department of Religion in Al-Qur'an dan Terjemahnya. He argued that the translation is entirely proper. Moreover, Shihab explains that the word (أولياء) auliya' is the plural form of the word (ولي) waliy. This word is taken from the rooted word consisting of the letters "wauw," lam, and ya', of which their basic meaning is close. From this word, new meanings develop such as supporter, defender, over, more critical, and the like, all of which are tied with the red thread, closeness. That is why a father is the most important person that becomes a waly for her daughter because he is the person who is closest to her. A person who is very obedient and diligent in worship is named waliy since he is close to Allah. A person who is friendly with another person so that they are

${ }^{44}$ Hamka, p. 1766-1767.

45 Hamka, p.1767. 
always together and share their secrets because of their closeness may also be called waly ${ }^{46}$.

It is also the case with a leader since he should be close to those he leads. The closeness is very significant so that it is he who first hears the call, even the complaints and whispering from anyone he leads, and due to this closeness, he is also the first person to come to help. Therefore, it is clear that all meanings proposed above may be covered by the word auliya'47.

Then M. Quraish Shihab cited the opinion given by a well-known mufassir from Shia, Thaba'thaba'i, about the word auliya'. According to Thaba'thaba'i, the word auliya' possesses the meaning of closeness to something that makes it lift and the disappearance of the boundary between what is approaching and what is being approached for the sake of reaching the goal of such closeness. In the context of holiness and help, the word auliya' may mean helpers. In association and affection, the word auliya' means the loved, and the interest is only in themselves. In the context of the family relation, the word waliy may tell someone who inherits it. No one may preclude the inheritance, while in the context of righteousness, the word waliy means who govern, and their provisions should be obeyed. ${ }^{48}$.

At a glance, this verse has a global connotation. Still, Tabatabai concludes that the word auliya' meant by this verse is a love that leads to the melting of differences in a container, the uniting souls that disagreed before, the interrelation of morals, and the similarity of the behaviors so that the two persons love one another as if they seem to have one soul, one desire and one deed that is not different from one another. This conclusion is emphasized by the following verse: "O You who believe! take not the Jews and Christians as Auliya' (friends. protector, helpers), they are but Auliya', then indeed he is one of them." Quraish Shihab adds a proverb, "Anyone who loves one group will include himself in the group" and "Someone will live together with the loved."

Related to the discussion of the closeness of love, there is one verse from AlQur'an that talks about it namely Q.S Al-Mumtahanah [60]:1:

\footnotetext{
${ }^{46}$ Quraish Shihab, Tafsir Al-Misbah, Jilid 3 (Jakarta: Lentera Hati, 2002), p. 123.

47 Shihab, p. 123.

48 Shihab, p. 123-124.
} 


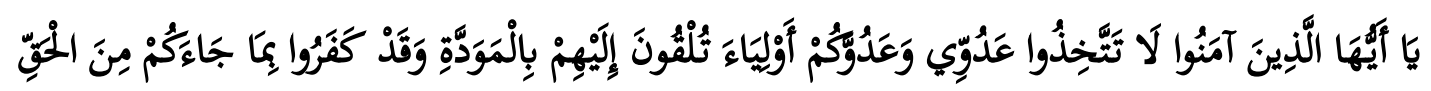

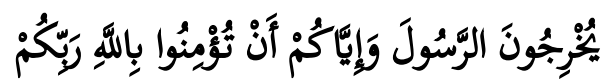

Translation:

O, Believers! Do not take my enemies and yours as trusted allies, showing them affection even though they deny what has come to you of the truth. They Drove the messenger and yourself out (or Mecca) simply for your belief in Allah, your lord if you truly emigrated to struggle in my cause and seek my pleasure, then do not take them as allies, disclosing secrets of the believers to the pagans out of affection for them, when I know best whatever you conceal and whatever you reveal and whoever of you does this has genuinely strayed from the right way.

Then in the ninth verse in the same surah, there are cauterized as the wrongdoing people. In Qs. Al-Mumtahanah [60]: 9, this is the same as what is mentioned by surah al-Maidah [5]: 51 surely Allah does not guide the wrongdoing people. Then Quraish Shihab explained that in verse 51 of the surah al-Maidah, it is prohibited to make non-Muslim people become auliya' and this prohibition is expressed using some confirmation among other (1) in an explicit prohibition stating that "don't take Jews and Christians as leaders (2) a confirmation that some of them are guardians of each other. (3) a threat for those appointing them as leaders. That they include into the group of wrongdoing people. But, M. Quraish Shihab stated that the prohibition is not absolute. He cited one of the explanations given by the mufasir figure, Sayyid Thantawi, which divides the non-Muslim people into three groups. The first is the people who live together with the Muslims peacefully. This group has the same social rights and obligations as the Muslims. There is no prohibition against making friends and against doing good things to them. God says that:

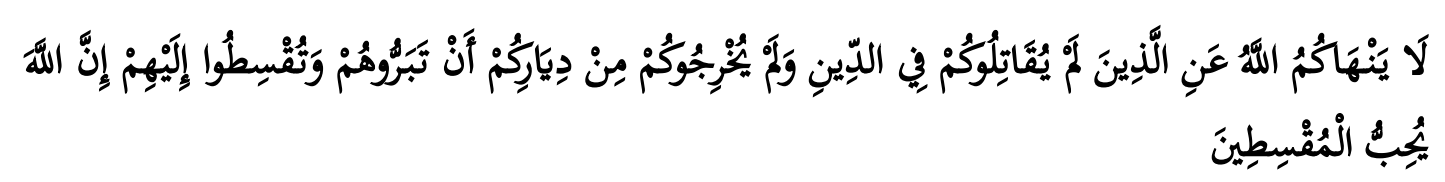

:Translation 
"Allah does not forbid you from dealing kindly and fairly with those who have neither fought nor driven you out of your homes. Surely Allah loves those who are fair" Surely Allah loves those who are fair." (Q.S. Al-Mumtahanah [60]: 8).

The second is the group that combats and is harmful to the Muslims. The Muslims are forbidden to establish a harmonious relationship with them. One of the verses of Al-Qur'an alludes to this group:

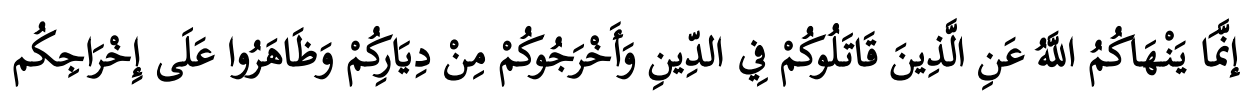

Translation:

Allah only forbids you from befriending those who have fought you for 'your' faith, driven you out of your homes, or supported 'others' in doing so. And whoever takes them as friends, then it is they who are the 'rue ${ }^{7}$ wrongdoers (QS. Al-Mumtahanah [60]: 9)

The third is the group that is not hostile to the Muslims, but some indicators show that they are more sympathetic to the enemy of Islam than the Muslims. To this group, Allah orders the believers to be always careful. Then, the last idiomatic expression of this verse is as follows: "Surely Allah does not guide the wrongdoing people." Quraish Shihab explains that what is meant by the last idiomatic expression in this verse does not give religious guidance to them, but they are not accompanied towards the way of happiness.

\section{The Comparison Between the Two Indonesian Interpretations}

Hamka and M. Quraish Shihab, in writing their interpretation book, used the same method, namely tahlili (analytical) method, namely interpreting verses in AlQur'an by exposing various aspects contained in the interpreted verses and explains the meanings included in them in line with the expertise and the tendency of the mufassirs interpreting the verses. ${ }^{49}$. Moreover, the two interpretation books possess a similar interpreting feature, namely adabi ijtima'i, a feature delineating and describing a social-based interpretation.

In terms of the writing systems of the book Tafsir Al-Azhar, Hamka gives more explanation on meanings contained in each sentence in its entirety. Hamka often relates his personal experiences in the process of interpreting a verse. He

\footnotetext{
${ }^{49}$ Baidan, “Wawasan Baru Ilmu Tafsir, p. 68.”
} 
also presents some historical data serving as an argument to boost his interpretation besides using legal rules. Different from M. Quraish Shihab, in the interpretation process, he always discusses each word with meanings that need to be explained in detail to develop its meanings. He also often includes asbab nuzul (if any) and cites other mufassirs opinions such as al-Biqa'i, Tabatabaei, and others.

Then, it comes to the interpretation of surah Al-Maidah verse 51. Either in the book Tafsir Al-Azhar or the book Tafsir Al-Misbah, the two mufassirs state that this verse contains a prohibition. Hamka states that this prohibition is absolute, while M. Quraish Shihab does not state that all non-Muslim people must do something terrible to the Muslims so that the prohibition is not absolute. Moreover, the word auliya' is not only translated into leaders, remembering that the phrase auliya' is a term with multi-interpretation, so M. Quraish Shihab prefers to describe meanings and their development word.

Something is interesting in the explanation made by Hamka about the prohibition in this verse. In his interpretation, Hamka gave an exception, different from M. Quraish Shihab. It is allowed to trust the non-Muslim people to hold a position with a note that the top leader should be held by Muslims, not necessary to be worried about any defection. Hamka stated that: "In an Islamic government, the Islamic rules are allowed to give trust to those with other beliefs to hold a position because the highest leader is under the hand of Islam. Therefore, there is no worry. But if concerns arise, it is not allowed."

From differences in the interpretation above, the author finds that the right to become a leader for non-Muslim circles is greatly limited since the permission is at the level of an exception. In the context of a democratic country, a model of interpretation should exist where it does not merely stick to a text but also considers marginalized groups so that it may give benefits widely without any discriminative elements, such as the distinction between the majority and the minority.

The existence of differences in interpretation between Hamka and M. Quraish Shihab shown in their two works, at the best knowledge of the author, is caused by some factors behind it, namely: 
The first is the educational factor. In a formal education, Hamka just studied up to the third grade of the village school, and he joined in one of the pesantren in his local area for a short time. His education was more dominated by reading by himself and being self-taught. Moreover, he also learned Islam when he was in Yogyakarta. Meanwhile, M. Quraish Shihab, since early childhood, has been educated under the direction of his father. Because in his family, education is the essential thing that should be given attention. Therefore, it is no wonder that from undergraduate to doctoral levels, he has worked in the same field in the same alma mater.

The second is the socio-political condition. Although the embryo of the book Tafsir AL-Azhar had existed since the Subuh recitation in the mosque Al-Azhar Jakarta, it cannot be denied that the writing of the book could be completed by Hamka when he was in jail under the administration of President Soekarno. Moreover, Hamka lived his life in one period of time, but he lived from the Dutch colonial period to the Old Order period. Therefore, it is natural if, in his interpretation, it is sometimes related to the social condition where he lived at that time. M. Quraish Shihab started writing the book Tafsir Al-Misbah on June 18, 1999. At that time, he held a position as the Indonesian ambassador for Egypt during the administration of President B.J. Habibie. ${ }^{50}$. The process of writing the interpretation book took about five years. M. Quraish Shihab completed the writing on 5 September 2003. Therefore, it can be stated that the book Tafsir Al-Misbach was written during the New Order government. So, it is no wonder if the presentation and interpretation made by Hamka in Tafsir Al-Azhar is in a little more burdensome condition than those of Tafsir Al-Misbah.

\section{E. Conclusion}

Hamka interprets the surah Al-Maidah verse 51 as an absolute prohibition to make non-Muslim leaders among Muslim people. He argues that non-Muslims will always try to do something terrible to Muslims. Meanwhile, M. Quraish Shihab interprets this verse as not to be an absolute prohibition against making nonMuslims as auliya'. He still divides non-Muslim into three parts. According to him, a

50 Shihab, Tafsir Al-Misbah: Pesan, Kesan dan Keserasian Al-Qur'an, p. 645. 
non-Muslim living peacefully with Muslims has the same right as Muslims, so that he has a right to become a leader.

In the authors ' opinion, the different interpretation presented by these two figures is caused by some factors. The first is that Hamka is known as a self-taught person in terms of education, and he learned a lot from reading activities. Meanwhile, for M. Quraish Shihab, from childhood to doctorate education, (formal) education is an important thing to be given attention. The second is the sociopolitical condition. Hamka wrote the book Tafsir Al-Azhar when he was in jail door two years under the administration of President Soekarno. Meanwhile, M. Quraish Shihab wrote the book Tafsir Al-Misbah when he became the Indonesian ambassador in Egypt during the administration of B.J. Habibie. Therefore, it is no wonder if the presentation and interpretation of the book Tafsir Al-Misbah are more subtle than those of the book Tafsir Al-Azhar.

In the book Tafsir Al-Misbah, although it is allowed for non-Muslim people to live together peacefully with the Muslims as auliya' The author thinks that this still depicts the existence of a partition between the majority group (Muslims) and the minority group (non-Muslims) by positioning the permission at the exception level. Whereas in a democratic country, all people have the same rights and obligations without discrimination based on the differences in beliefs and the like. Therefore, the author thinks that it is necessary to have an interpretation focused on the text and one that considers the social condition of the marginalized groups at present so that it may give benefits at large.

\section{References}

Ahnaf, Mohammad Iqbal. '“Aksi Bela Islam,' Akankah Mengubah Lanskap Muslim Indonesia?” Maarif, 2016.

Baidan, Nashruddin. "Wawasan Baru Ilmu Tafsir.” Buku, 2016.

Burhani, Ahmad Najib. "Aksi Bela Islam: Konservatisme Dan Fragmentasi Otoritas Keagamaan." Jurnal Maarif Institute, 2016.

Hamka. Ayahku: Riwayat Hidup Dr. H. Abdul Karim Amrullah Dan Perjuangan Kaum Agama Di Sumatera, 1982.

_—_. Tafsir Al-Azhar. 3rd ed. Singapura: Kerjaya Print, 2007.

Hasan Muarif Ambary. “Suplemen Ensiklopedi Islam.” In Ensiklopedi Islam, 1996.

Herry, Mohammad. Tokoh-Tokoh Islam Yang Berpengaruh Abad 20. Gema Insani, 2006. 
Ismail, Norbani B. "The Qur'anic Exegesis, Reformism, and Women in Twentieth$\begin{array}{llll}\text { Century Indonesia." } & \text { Studia }\end{array}$ https://doi.org/10.15408/sdi.v24i3.5187.

Izzah, Latifatul. "Melihat Potret Harmonisasi Hubungan Antar Umat Beragama." Jurnal Studi Agama-Agama Kompetensi Damai Dalam Keragaman 9, no. 1 (2013): 1-22.

Junaedi, Dedi. "Konsep Dan Penerapan Takwil Muhammad Quraish Shihab Dalam Tafsir Al-Mishbah.” Wawasan: Jurnal Ilmiah Agama Dan Sosial Budaya, 2017. https://doi.org/10.15575/jw.v2i2.1645.

Lufaefi, Lufaefi. "Tafsir Al-Mishbah: Tekstualitas, Rasionalitas Dan Lokalitas Tafsir Nusantara." Substantia: Jurnal Ilmu-Ilmu Ushuluddin, 2019. https://doi.org/10.22373/substantia.v21i1.4474.

M. Bibit Suprapto. Ensiklopedia Ulama Nusantara. Jakar: Gelagar Media indonesia, n.d.

Malkan, Malkan. "Tafsir Al-Azhar: Suatu Tinjauan Biografis Dan Metodologis." HUNAFA: Jurnal Studia 2009. https://doi.org/10.24239/jsi.v6i3.146.359-376.

Muh. Mustakim, Syamsul Arifin, Moh Nurhakim, Akhsanul In'am. Spiritualisasi Pendidikan Qur'ani. Cilacap: Pasific Press, 2020.

Nasir Tamara, dkk. Hamka Di Mata Hati Umat. Jakarta: Pustaka Sinar harapan, 1996.

Shihab, M. Quraish. Lentera Al-Qur'an: Kisah Dan Hikmah Kehidupan. Bandung: PT Mizan Pustaka, 2014.

- - Membumikan Al-Qur'an: Fungsi Dan Peran Wahyu Dalam Kehidupan Masyarakat. Bandung: Mizan, 2007.

-_- Tafsir Al-Misbah: Pesan, Kesan Dan Keserasian Al-Qur'an. Ciputat: Penerbit Lentera Hati, 2011.

Shihab, Quraish. Tafsir Al-Misbah. Jakarta: Lentera Hati, 2002.

Shobahussurur. Mengenang 100 Tahun Haji Abdul Malik Karim Amrullah (Hamka). Jakarta: Yayasan Pesantren Islam al-Azhar, 2008.

Supyan, Muhammad Dian. "Kepemimpinan Islam Dalam Tafsir Al-Misbah Karya M Quraish Shihab.” UIN Sunan Kalijaga, 2013.

Suryana, A'an. "Islam Dan Urusan Kemanusiaan: Konflik Perdamaian Dan Filantropi." Global South Review, 2017. https://doi.org/10.22146/globalsouth.28855.

Susanto, A. Pemikiran Pendidikan Islam. Jakarta: Amzah, 2009.

Syahrul, Achmad. Penafsiran Hamka Tentang Syura in Tafsir Al-Azhar. Fakultas Ushuluddin dan Pemikiran Islam, 2009.

Wartini, Atik. "Corak Penafsiran M. Quraish Shihab dalam Tafsir Al-Misbah." HUNAFA: Jurnal Studia Islamika, 2014. https://doi.org/10.24239/jsi.v11i1.343.109-126.

Yunan Yusuf. Corak Pemikiran Kalam Tafsir Al-Azhar. Jakarta: Pustaka Panjimas, 1990. 